Zeszyty Naukowe Szkoły Głównej Gospodarstwa Wiejskiego w Warszawie

Problemy Rolnictwa Światowego tom 18 (XXXIII), zeszyt 3, 2018: 262-271

DOI: $10.22630 /$ PRS.2018.18.3.84

Anna Maria Rak ${ }^{1}$

Uniwersytet Przyrodniczo-Humanistyczny w Siedlcach

\title{
Aktywizacja zawodowa młodych osób bezrobotnych w wybranych powiatach ziemskich podregionu siedleckiego
}

\section{Vocational Activation of Young Unemployed in Selected Rural Counties of Siedlce Subregion}

\begin{abstract}
Synopsis. Bezrobocie osób młodych należy aktualnie do najpoważniejszych problemów polskiego i unijnego rynku pracy. Na obydwu tych rynkach osoby młode stanowią blisko połowę ogółu bezrobotnych. Celem niniejszego opracowania jest określenie stopnia zainteresowania bezrobotnych młodych mieszkańców wsi aktywnymi programami rynku pracy oraz diagnoza najczęściej stosowanych przez te osoby metod poszukiwania zatrudnienia. Podstawowym źródłem informacji są wyniki badań ankietowych przeprowadzonych $\mathrm{w}$ trzech powiatach ziemskich podregionu siedleckiego.
\end{abstract}

Slowa kluczowe: bezrobocie osób młodych, aktywne programy rynku pracy, metody poszukiwania zatrudnienia

\begin{abstract}
Youth unemployment is currently among the most serious problems on the Polish and EU labour markets. The young account for nearly half of the unemployed on the two markets. The purpose of the paper is to determine the interest of young unemployed residents of rural areas in labour market programmes and to diagnose the methods of seeking employment used by those people. The information presented mainly comes from the results of questionnaire surveys carried out in three rural counties of the Siedlce subregion.
\end{abstract}

Key words: youth unemployment, active labour market programmes, methods of seeking employment

JEL Classification: J64

\section{Wprowadzenie}

Według danych Eurostatu zharmonizowana stopa bezrobocia w Unii Europejskiej w końcu czerwca 2018 roku osiagnęła poziom 6,9\%. Spośród wszystkich państw członkowskich najniższy poziom bezrobocia odnotowano w Czechach, w Niemczech i na Węgrzech. Polska z wynikiem 3,7\% uplasowała się na pozycji czwartej. Wyraźny trend spadkowy bezrobocia w UE obserwowany jest od roku 2014.

Większość ekonomistów ocenia, iż ze względu na niedostateczny rozmiar podaży aktualny rynek pracy wykazuje cechy rynku pracownika. W tej sytuacji za problem najtrudniejszy do rozwiązania uznaje się bezrobocie osób młodych, które stanowią blisko połowę ogółu bezrobotnych. Na koniec czerwca 2018 roku stopa bezrobocia w UE wśród osób do 25. roku kształtowała się na poziomie 15,2\%. Osoby młode, to grupa społeczno-

${ }^{1}$ dr inż., Wydział Nauk Ekonomicznych i Prawnych UPH w Siedlcach, ul. Żytnia 17/19, 08-110 Siedlce, e-mail: arak@uph.edu.pl; https://orcid.org/0000-0002-5859-6252 
zawodowa, przed którą rynek pracy stawia szczególnie wysokie wymagania. Pracodawcy poszukują pracowników wykwalifikowanych, posiadających doświadczenie i staż pracy, których ludzie młodzi, często tuż po zakończeniu edukacji, ze względów oczywistych nie posiadaja. Skuteczna aktywizacja zawodowa tej grupy bezrobotnych, stałaby się przynajmniej w części odpowiedzią na zgłaszane przez pracodawców niedobory zasobów pracy.

W aktywizacji zawodowej osób młodych szczególnego znaczenia nabiera polityka rynku pracy, która stanowi trwały element współczesnej polityki gospodarczej krajów wysokorozwiniętych i znajduje umocowanie w najważniejszych aktach prawnych (Ostój, 2012). Próby ograniczania problemu jednoznacznie określone zostały również w dokumentach wspólnotowych, w tym przede wszystkim w „Strategii Unii Europejskiej na rzecz młodzieży” oraz w dokumencie „Europa 2020 - Strategia na rzecz inteligentnego i zrównoważonego rozwoju sprzyjającemu włączeniu społecznemu" (Kaczmarczyk, 2016).

Porównanie skali bezrobocia osób młodych na wsi i w mieście, wskazuje na większe natężenie problemu w środowiskach wiejskich (Aktywność..., 2016, 2018). Z uwagi na ekonomiczno-społeczne konsekwencje bezrobocia młodych mieszkańców wsi, zjawisko to wymaga szczegółowej diagnozy, w tym również w odniesieniu do lokalnych rynków pracy.

Celem niniejszego opracowania jest określenie stopnia zainteresowania bezrobotnych młodych mieszkańców wsi aktywnymi programami rynku pracy oraz diagnoza najczęściej stosowanych przez te osoby metod poszukiwania zatrudnienia.

Podstawowym źródłem informacji są wyniki badań ankietowych przeprowadzonych techniką PAPI (Paper Assisted Personal Interviewing) na terenie trzech powiatów ziemskich (siedleckiego, sokołowskiego i łosickiego) podregionu siedleckiego. Podregion siedlecki położony jest we wschodniej części Regionu Mazowieckiego Regionalnego. Poważnym problemem podregionu nadal pozostaje bezrobocie osób młodych. Udział osób bezrobotnych do 34 roku życia waha się od $46,3 \%$ w powiecie węgrowskim do $49,7 \%$ w powiecie siedleckim. Są to wskaźniki zdecydowanie wyższe niż dla kraju (40,4\%) oraz dla województwa mazowieckiego (38,3\%).

Badaniami zrealizowanymi w styczniu i lutym 2018 roku objęto 120 osób w wieku od 18 do 34 roku życia. Każda z badanych osób spełniała kryteria osoby bezrobotnej przyjęte w definicji stosowanej przez GUS w Badaniach Aktywności Ekonomicznej Ludności (BAEL). Badania przeprowadzono z wykorzystaniem kwestionariusza ankiety, w którym uwzględnione zostały uwzględnione zostały pytania dotyczące sytuacji rodzinnej i materialnej, wykształcenia, istotnych wartości życiowych i zawodowych oraz aktywności edukacyjnej i aktywności w zakresie poszukiwania pracy.

\section{Przyczyny i konsekwencje bezrobocia osób młodych na wiejskim rynku pracy}

Według danych BAEL w okresie pomiędzy I kwartałem 2016 a I kwartałem 2018 roku, stopa bezrobocia w Polsce wśród osób do 34 roku życia spadła o 4,3 p.p., w tym na wsi o 4,6 p.p., natomiast w mieście o 4,0 p.p. W I kwartale 2018 roku wskaźnik ten na wsi osiagnął poziom 7,9\%, a w mieście 5,1\% (Aktywność..., 2016, 2018). W rzeczywistości problem bezrobocia na wsi jest większy niż wynika to z różnicy stopy bezrobocia pomiędzy wsią a miastem. Należy bowiem uwzględnić fakt, że przyjęta w BAEL definicja bezrobotnego opiera się na standardach Międzynarodowej Organizacji Pracy i nie jest 
związana z faktem rejestracji. Jest ona bardziej rygorystyczna w stosunku do tej stosowanej przez urzędy. W rozumieniu Międzynarodowej Organizacji Pracy bezrobotnym pozostaje osoba niepracująca zarobkowo więcej niż 1 godzinę w badanym tygodniu, która aktywnie poszukuje pracy i jest gotowa do podjęcia pracy w tygodniu badanym lub następnym. Kryteria te częściej spełniają bezrobotni mieszkający na wsi, którzy z braku innych zajęć na ogół uczestniczą w pracach gospodarstw rolnych.

Mimo znacznego w ostatnim okresie ograniczenia problemu bezrobocia na polskim rynku pracy, wskaźniki bezrobocia wśród osób młodych są znacznie wyższe w porównaniu z pozostałymi kategoriami wieku. Oznacza to, że nadal jest to grupa pozostająca w najtrudniejszej sytuacji na rynku pracy. Do najważniejszych przyczyn bezrobocia osób młodych zalicza się brak doświadczenia zawodowego i niedopasowanie kwalifikacji do potrzeb rynku pracy. W procesie rekrutacji pracodawcy szukają kandydatów, którzy są w stanie wnieść do rozwijającego się biznesu realną wartość. Jest mniej prawdopodobne, że taką wartość wniesie młody człowiek bez doświadczenia zawodowego, który ponadto generuje koszty dokształcenia i dostosowania.

Występowaniu problemów bezrobocia osób młodych sprzyja także system edukacji, w tym również na poziomie szkolnictwa wyższego (Chłoń-Domińczak, Strawiński, 2015). W okresie ostatnich 20 lat współczynniki skolaryzacji w szkolnictwie wyższym wzrosły ponad dwukrotnie. Współczynnik skolaryzacji brutto wzrósł z 22,3\% w roku akademickim 1995/1996 do 47,6\% w roku akademickim 2015/2016 ${ }^{2}$. Ma to bezpośredni wpływ na liczbe wchodzących na rynek pracy absolwentów kierunków studiów wyższych. Ponadto poważnym problemem dotyczącym wielu szkół wyższych jest brak zgodności programów kształcenia z potrzebami zgłaszanymi przez pracodawców. 2013):

Wśród przyczyn problemów bezrobocia osób młodych wymienia się również (Piróg,

- dyskryminujące młodzież praktyki rekrutacyjne pracodawców,

- brak postaw sprzyjających skutecznemu poszukiwaniu pracy,

- zbyt wygórowane żądania płacowe w stosunku do ofert rynku pracy.

Konsekwencje bezrobocia osób młodych rozpatrywać należy z uwzględnieniem skutków o charakterze społecznym oraz makro- i mikroekonomicznym (Kaczmarczyk, 2016, Księżyk, 2015). Do skutków społecznych zalicza się podwyższone prawdopodobieństwo ubóstwa, marginalizacji lub nawet wykluczenia społecznego. Tego typu zjawiska skutkować mogą z kolei pojawianiem się zachowań patologicznych, takich jak przestępczość, alkoholizm czy narkomania. Negatywnym efektem bezrobocia młodych jest także deprecjacja posiadanych umiejętności i kompetencji zawodowych oraz wydłużanie się procesu usamodzielnienia.

Skutki makroekonomiczne związane są brakiem udziału bezrobotnych w tworzeniu dochodu narodowego, stratami budżetowymi wynikającymi z ponoszenia nakładów na edukację oraz finansowaniem aktywnych i pasywnych instrumentów rynku pracy. Konsekwencje mikroekonomiczne odnoszą się do trudnej sytuacji dochodowej osoby bezrobotnej przenoszonej również na innych członków gospodarstwa domowego.

\footnotetext{
${ }^{2}$ Współczynnik skolaryzacji brutto jest to wyrażony procentowo stosunek (według stanu w dniu 31 grudnia) wszystkich osób uczących się na danym poziomie do całej populacji osób będących w wieku nominalnie przypisanym temu poziomowi kształcenia (19-24 lata w przypadku szkolnictwa wyższego).
} 


\section{Wybrane elementy polityki rynku pracy}

W aktywizacji zawodowej osób młodych szczególnego znaczenia nabiera polityka rynku pracy, która zmierza do realizacji pięciu następujących celów (Frączek, 2015):

1. Celu zatrudnieniowego powodującego ograniczenie rozmiarów bezrobocia;

2. Celu strukturalnego ukierunkowanego na zmniejszenie niedopasowań strukturalnych;

3. Celu produkcyjnego związanego z podnoszeniem efektywności zasobu pracy;

4. Celu socjalnego zabezpieczenia osób dotkniętych bezrobociem;

5. Celu integracji zawodowej tzw. grup problemowych na rynku pracy.

Uwzględniając cele polityki rynku pracy można wyodrębnić w jej ramach instrumenty aktywne i pasywne (in. aktywne i pasywne programy rynku pracy). Instrumenty aktywne stwarzają bezrobotnemu możliwości podjęcia pracy lub podnoszą jego szanse zatrudnieniowe (Drela, Kiernożycka-Sobejko, 2009). Wpływają one na poziom mobilności czynnika pracy, a także na osłabienie presji inflacyjnej i podniesienie możliwości zatrudnienia nawet przy danych rozmiarach popytu zagregowanego.

Instrumenty pasywne pełnią funkcje osłonowe poprzez łagodzenie skutków bezrobocia. Należą do nich zasiłki dla bezrobotnych oraz narzędzia ukierunkowane na zmniejszenie podaży pracy (np. wydłużenie okresu kształcenia czy dzielenie miejsc pracy). Odpowiednio skonstruowane narzędzia pasywne mogą także motywować bezrobotnych do aktywnego poszukiwania zatrudnienia (Kubiak, 2016). Oddziaływanie motywujące spełnia zwykle obniżanie wysokości zasiłku bądź utrata prawa do tego świadczenia wraz z wydłużaniem się okresu pozostawania bez pracy.

Z punktu widzenia aktywizacji zawodowej osób młodych zdecydowanie większą rolę pełnią narzędzia o charakterze aktywnym. Ich znaczenie w zakresie wychodzenia $\mathrm{z}$ bezrobocia i uzyskania trwałego zatrudnienia odnosi się przede wszystkim do poziomu mikroekonomicznego (Socha, Sztanderska, 2000). Ustawa o promocji zatrudnienia definiuje trzy rodzaje instrumentów aktywnych (Frączek, 2015):

1. podstawowe usługi rynku pracy (pośrednictwo pracy, poradnictwo zawodowe, organizacja szkoleń),

2. instrumenty rynku pracy wspierające podstawowe usługi rynku pracy (między innymi staże, roboty publiczne, programy specjalne i regionalne, przyznawanie bezrobotnemu spełniającemu środków na podjęcie działalności gospodarczej, bony stażowe, szkoleniowe i zatrudnieniowe dla osób bezrobotnych do 30 roku życia),

3. instrumenty rozwoju zasobów rynku pracy (Krajowy Fundusz Szkoleniowy, program zwolnień monitorowanych, świadczenia szkoleniowe dla zwalnianych pracowników).

Działania mające na celu zwiększenie efektywności tych programów oraz inne rozwiązania w zakresie aktywizacji bezrobotnych wprowadzone zostały Ustawą z dnia 14 marca 2014 roku o zmianie ustawy o promocji zatrudnienia i instytucjach rynku pracy oraz innych ustaw (Dz. U. z 2014 r., poz. 598). a także Rozporządzeniem Ministra Pracy i Polityki Społecznej z dnia 14 maja 2014 roku w sprawie profilowania pomocy dla bezrobotnego (Dz. U. z 2014 r., poz. 631). Głównym zadaniem wymienionych aktów prawnych ma być usprawnienie oddziaływania polityki rynku pracy na wzrost zatrudnienia oraz łagodzenie skutków niedopasowania strukturalnego, zwłaszcza pod kątem kwalifikacji i kompetencji osób bezrobotnych. Zaplanowane działania mają na celu przywracanie umiejętności osób bezrobotnych do trwałego włączania się do rynku pracy oraz poprawę efektywności: 
- polityki rynku pracy (w tym dzięki lepszej współpracy z pracodawcami);

- funkcjonowania urzędów pracy, w tym podniesienia standardów obsługi klientów przez te urzędów i uzyskiwanych przez nie wskaźników zatrudnienia, dzięki wprowadzeniu nowych form organizacji pracy oraz współpracy urzędów z podmiotami niepublicznymi.

Istotnym zapisem tej ustawy jest zakwalifikowanie osób do 30. roku życia (a nie jak poprzednio do 25. roku ) do grupy znajdującej się w szczególnej sytuacji na rynku pracy. Oznacza to, że dostęp do programów specjalnych oferowany będzie wszystkim absolwentom. Uzasadnieniem dla powyższego rozwiązania jest fakt ukończenia 25 lat przez większość osób studiujących (24\%) i kończących studia (ok. 70\%).

Dla młodych osób bezrobotnych znowelizowana ustawa wprowadziła rozwiązania w postaci bonów (stażowych, szkoleniowych, zatrudnieniowych i na zasiedlenie), a także refundację składek na ubezpieczenie społeczne dla pracodawców za zatrudnienie bezrobotnego w wieku do 30 roku życia podejmującego pracę po raz pierwszy.

Nowelizacja ustawy nakłada na urzędy pracy obowiązek profilowania osób bezrobotnych. Ma to na celu podniesienie skuteczności działań urzędów we wchodzeniu lub powrocie na rynek pracy osób w największym stopniu tej pomocy potrzebujących, a do tych zaliczane są również osoby młode. Osoby bezrobotne tuż po rejestracji w urzędzie aktywizowane są $\mathrm{w}$ oparciu o zindywidualizowane podejście, wyrażone poprzez przyporządkowanie do jednego z trzech wyodrębnionych profili. Każdy zarejestrowany bezrobotny, od momentu rejestracji prowadzony jest przez tego samego pracownika urzędu, tzw. doradcę klienta. Aktywizacja od samego początku prowadzona jest w oparciu o Indywidualny Plan Działania, z uwzględnieniem potencjału aktywizacyjnego wyrażonego w przyporządkowaniu do określonego profilu.

\section{Wyniki badań}

W przeprowadzonych badaniach ankietowych udział wzięło 47 kobiet i 73 mężczyzn. Najliczniejszą grupę $(40,8 \%)$ stanowily osoby bezrobotne w wieku $18-24$ lata. Najwyższy odsetek bezrobotnych właśnie z tej kategorii wieku jest w ostatnich latach typowy dla polskiego rynku pracy. Wśród badanych osoby z grupy $25-29$ lata stanowiły $28,3 \%$, natomiast z grupy $30-34$ lata $-30,9 \%$.

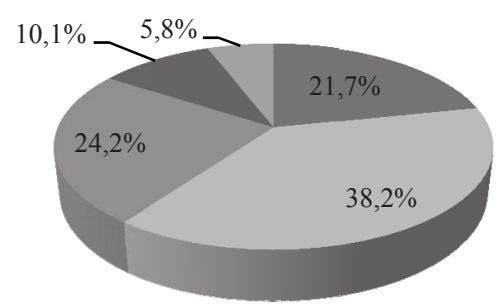

$$
\begin{aligned}
& \text { wyższe } \\
& \text { policealne i średnie } \\
& \text { zawodowe } \\
& \text { średnie ogólnokształcące } \\
& \text { - zasadnicze zawodowe } \\
& \text { qimnazjalne i poniżej }
\end{aligned}
$$

Rys. 1. Struktura wykształcenia respondentów

Fig. 1. The structure of respondents' education

Źródło: opracowanie własne na podstawie wyników badań ankietowych.

W każdej analizie bezrobocia należy uwzględnić poziom wykształcenia osób bezrobotnych (rys. 1) uznawany za czynnik kluczowy determinujący szanse znalezienia 
satysfakcjonującego i trwałego zatrudnienia. W ankietowanej zbiorowości grupa najliczniejszą byli bezrobotni legitymujący się wykształceniem średnim zawodowym $(38,2 \%)$. Znaczący odsetek stanowili również absolwenci liceów ogólnokształcących $(24,2 \%)$. Jest to jedyna kategoria bezrobotnych, której pozycja na polskim rynku pracy w ostatnim okresie uległa pogorszeniu, a co związane jest z brakiem zapotrzebowania na pracowników niewykwalifikowanych.

W zbiorowości osób badanych (rys. 1) stosunkowo najniższy udział stanowili bezrobotni z wykształceniem wyższym $(21,7 \%)$. Z jednej strony ukończenie studiów nadal pozostaje cennym składnikiem kapitału intelektualnego, stwarzającym duże szanse na zatrudnienie, z drugiej zaś, utrzymująca się w I kwartale 2018 roku dla tej grupy absolwentów stopa bezrobocia na poziomie $17,3 \%$ przy stopie ogółem 4,2\% (Aktywność...2018), jest między innymi rezultatem niedostosowania kierunków kształcenia do potrzeb rynku pracy (Chłoń-Domińczak, Strawiński, 2015). Wśród bezrobotnych $\mathrm{z}$ wykształceniem wyższym, duża grupa osób uzyskuje dyplomy na kierunkach nie dających perspektyw na zatrudnienie.

W grupie ankietowanych najliczniej reprezentowana jest kategoria bezrobotnych, którzy utracili zatrudnienie (57,5\% ogółu). Jest to dość zaskakujące w sytuacji niezłej koniunktury gospodarczej i zgłaszanych przez przedsiębiorców niedoborów pracowniczych. Można więc sądzić, że są to między innymi bezrobotni, których umiejętności i kompetencje zawodowe nie spełniały oczekiwań pracodawców. Wśród badanych udział osób podejmujących próbę znalezienia pracy po raz pierwszy wynosił $22,5 \%$, osób powracających na rynek pracy po przerwie $15,8 \%$, a tych, którzy sami zrezygnowali z poprzedniego miejsca pracy $4,2 \%$.

Większość ankietowanych (93 respondentów) deklaruje znaczne doświadczenie zawodowe. Spośród nich aż 47,5\% posiada doświadczenie nabyte w więcej niż trzech miejscach pracy. Znajduje to odzwierciedlenie w strukturze respondentów według długości okresu pozostawania bez pracy. Najwyższy odsetek (77,5\% ogółu) stanowią bezrobotni pozostający bez pracy w okresie do 6 miesięcy. Biorąc pod uwagę konsekwencje bezrobocia długoterminowego, negatywnie należy ocenić 13,3\% udział osób pozostających bezrobotnymi powyżej 1 roku. Bezrobocie długookresowe jest wyjątkowo trudne do likwidacji, ponieważ odpływ do zatrudnienia najsilniej następuje w początkowym okresie bezrobocia, później szanse na zatrudnienie stopniowo maleja, a kapitał ludzki ulega deprecjacji. Według badań przeprowadzonych przez CBOS osoby pozostające bez pracy w dłuższym okresie czasu rzadziej podejmują wysiłek znalezienia zatrudnienia, mają znacznie mniejsze kwalifikacje i brak motywacji do ich podnoszenia (Bezrobotni..., 2007).

Analiza danych przedstawionych w tabeli 1 wskazuje na bardzo niski stopień korzystania $\mathrm{z}$ aktywnych form przeciwdziałania bezrobociu. Z tego typu programów skorzystało zaledwie 26 respondentów (21,6\% ogółu badanych). Największa liczba bezrobotnych ( 9 osób) w ramach aktywizacji oferowanej przez powiatowe urzędy pracy korzystała ze staży. Staż jest programem skierowanym głównie do osób młodych, który umożliwia im zdobycie doświadczenia zawodowego przez okres 6 lub w przypadku bezrobotnych do 30 roku życia, przez okres 12 miesięcy. Bezrobotni objęci tym programem nabywają jednocześnie prawo do stypendium w wysokości $120 \%$ zasiłku dla bezrobotnych. W sytuacji osób młodych, zwłaszcza absolwentów, staże są niewątpliwie formą aktywizacji zdecydowanie zwiększającą szanse na zatrudnienie.

Spośród badanych 6 osób wskazało udział w szkoleniach o tematyce dotyczącej uruchomienia i prowadzenia własnej działalności gospodarczej. Każda z tych osób 
zadeklarowała również zainteresowanie skorzystaniem w najbliższym okresie z dotacji na założenie własnej firmy.

Wykorzystanie pozostałych ujętych w kwestionariuszu ankietowym form aktywizujących było znikome. Plany korzystania z aktywnych instrumentów rynku pracy dotyczyły najczęściej przystąpienia do programu polegającego na pozyskaniu jednorazowych środków na podjęcie działalności gospodarczej.

Jako bardzo niski należy również ocenić poziom wiedzy na temat funkcjonowania programów aktywizujących. Najwyższy poziom wiedzy osoby ankietowane deklarowały w odniesieniu do dotacji na uruchomienie własnej firmy oraz pożyczki na założenie własnej firmy.

Tabela 1. Korzystanie z programów oraz poziom wiedzy o zasadach funkcjonowania aktywnych programów rynku pracy (\% wskazań dla poszczególnych form aktywizujących)

Table 1. Usage of activation programs and the level of knowledge about the rules of functioning of active labor market programs ( $\%$ indications for particular forms of activation)

\begin{tabular}{|c|c|c|c|c|}
\hline Nazwa programu & $\begin{array}{l}\text { Korzystałem } \\
\text { /am }\end{array}$ & $\begin{array}{c}\text { Chcę } \\
\text { skorzystać }\end{array}$ & $\begin{array}{l}\text { Znam zasady, } \\
\text { ale nie } \\
\text { korzystałem/am }\end{array}$ & $\begin{array}{c}\text { Nie mam } \\
\text { żadnej } \\
\text { wiedzy }\end{array}$ \\
\hline $\begin{array}{l}\text { Jednorazowe środki na podjęcie działalności } \\
\text { gospodarczej }\end{array}$ & - & 21,7 & 29,1 & 49,2 \\
\hline Pożyczka na podjęcie działalności gospodarczej & - & 5,8 & 33,3 & 60,9 \\
\hline Prace interwencyjne & 1 & 0,8 & 10,0 & 88,4 \\
\hline Prace społecznie użyteczne & - & - & 9,2 & 90,8 \\
\hline Roboty publiczne & 1 & 0,8 & 5,8 & 92,6 \\
\hline Przygotowanie zawodowe dorosłych & 1 & 3,3 & 6,7 & 89,2 \\
\hline Staże & 7,5 & 0,8 & 10,8 & 80,9 \\
\hline Zwrot kosztów przejazdu i zakwaterowania & 2,5 & 1,7 & 4,2 & 91,6 \\
\hline Zwrot kosztów opieki nad dzieckiem & - & - & 4,2 & 95,8 \\
\hline Zwrot kosztów przejazdu na badania & 0,8 & 0,8 & 3,4 & 95,0 \\
\hline Bon stażowy & - & - & 3,3 & 96,7 \\
\hline Bon szkoleniowy & 0,8 & 0,8 & 3,4 & 95,0 \\
\hline Bon zatrudnieniowy & 0,8 & 1,7 & 3,3 & 94,2 \\
\hline Bon na zasiedlenie & - & 1,7 & 3,3 & 95,0 \\
\hline Program aktywizacja i integracja & 1,7 & 3,3 & 2,5 & 92,5 \\
\hline Szkolenia dla osób bezrobotnych & 5,0 & 7,5 & 5,8 & 81,7 \\
\hline Pożyczka szkoleniowa & - & - & 4,2 & 95,8 \\
\hline Finansowanie kosztów egzaminów i licencji & - & 1,7 & 3,3 & 95,0 \\
\hline Stypendium z tytułu podjęcia dalszej nauki & - & 0,8 & 3,3 & 95,8 \\
\hline Dofinansowanie studiów podyplomowych & - & 0,8 & 3,3 & 95,8 \\
\hline
\end{tabular}

Źródło: opracowanie własne na podstawie wyników badań ankietowych.

Nieznaczny stopień zainteresowania aktywnymi instrumentami rynku pracy oraz niski poziom wiedzy na temat tych instrumentów można tłumaczyć tym, iż 43,3\% ogółu respondentów w dniu prowadzania badania pozostawało poza rejestrami powiatowych 
urzędów pracy. Ponadto aż 77,5\% ogółu badanych zadeklarowało okres bezrobocia krótszy niż 6 miesięcy. Można więc przyjąć, że okres zdobywania wiedzy o formach aktywizacji bezrobotnych był również stosunkowo krótki. Przyczyną niewielkiego zainteresowania instrumentami typowymi dla bezrobotnych osób młodych, takich jak staże czy bony, jest także znaczące doświadczenie zawodowe osób objętych badaniami. Jak zaznaczono w podrozdziale poprzednim, 93 respondentów posiadało doświadczenie zawodowe, w tym 44,0\% spośród nich w więcej niż trzech miejscach pracy.

Osoby badane podejmując próbę znalezienia pracy korzystały średnio z trzech metod poszukiwania zatrudnienia (tab. 2). Metodą najczęściej stosowaną przez respondentów była analiza ofert publikowanych przez urzędy pracy. Tę formę poszukiwania zatrudnienia wskazała jedna trzecia osób z wykształceniem gimnazjalnym i średnim oraz jedna czwarta respondentów legitymujących się wykształceniem wyższym i zasadniczym zawodowym. Powszechną praktyką każdej grupy wyodrębnionej ze względu na poziom wykształcenia było również śledzenie ofert publikowanych w mediach. Wskazując tę praktykę osoby badane wymieniały przede wszystkim portale internetowe. Popularną formą poszukiwania pracy wśród ankietowanych było także korzystanie z kontaktów krewnych i znajomych (29,0\% wskazań w grupie osób z wykształceniem zasadniczym zawodowym, 20,0\% w grupie z wykształceniem wyższym, $15,6 \% \mathrm{w}$ grupie z wykształceniem średnim i 12,5\% z wykształceniem gimnazjalnym). Metody najczęściej wskazywane przez respondentów to jednocześnie te, które zgodnie z wynikami BAEL są najbardziej popularnymi wśród bezrobotnych w Polsce (Aktywność..., 2018).

Tabela 2. Metody poszukiwania pracy według kryterium wykształcenia respondentów

Table 2. Methods of looking for a job according to the education criterion of respondents

\begin{tabular}{|c|c|c|c|c|c|c|c|c|}
\hline \multirow{2}{*}{ Wyszczególnienie } & \multicolumn{2}{|c|}{ Wyższe } & \multicolumn{2}{|c|}{ Średnie } & \multicolumn{2}{|c|}{$\begin{array}{l}\text { Zasadnicze } \\
\text { zawodowe }\end{array}$} & \multicolumn{2}{|c|}{$\begin{array}{l}\text { Gimnazjalne } \\
\text { i niższe }\end{array}$} \\
\hline & $\begin{array}{c}\text { liczba } \\
\text { wskazań }\end{array}$ & $\%$ & $\begin{array}{c}\text { liczba } \\
\text { wskazań }\end{array}$ & $\%$ & $\begin{array}{c}\text { liczba } \\
\text { wskazań }\end{array}$ & $\%$ & $\begin{array}{c}\text { liczba } \\
\text { wskazań }\end{array}$ & $\%$ \\
\hline Analiza ofert urzędów pracy & 20 & 26,6 & 66 & 29,5 & 8 & 25,8 & 5 & 31,3 \\
\hline $\begin{array}{l}\text { Zamieszczanie własnej oferty w } \\
\text { mediach }\end{array}$ & 2 & 2,7 & 6 & 2,7 & 1 & 3,2 & 2 & 12,5 \\
\hline $\begin{array}{l}\text { Analiza ofert publikowanych } \\
\text { w mediach }\end{array}$ & 18 & 24,0 & 57 & 25,4 & 7 & 22,6 & 5 & 31,3 \\
\hline $\begin{array}{l}\text { Starania w zakresie podjęcia } \\
\text { pracy na rynkach zagranicznych }\end{array}$ & 1 & 1,3 & 7 & 3,1 & - & - & - & - \\
\hline $\begin{array}{l}\text { Korzystanie z pomocy krewnych } \\
\text { i znajomych }\end{array}$ & 15 & 20,0 & 35 & 15,6 & 9 & 29,0 & 2 & 12,5 \\
\hline Wysyłanie ofert do pracodawców & 5 & 6,7 & 6 & 2,7 & 1 & 3,2 & 1 & 6,3 \\
\hline $\begin{array}{l}\text { Bezpośrednie wizyty w } \\
\text { zakładach pracy }\end{array}$ & 12 & 16,0 & 44 & 19,6 & 4 & 12,9 & - & - \\
\hline $\begin{array}{l}\text { Brak aktywności w zakresie } \\
\text { poszukiwania pracy }\end{array}$ & 2 & 2,7 & 3 & 1,3 & 1 & 3,2 & 1 & 6,3 \\
\hline
\end{tabular}

Źródło: opracowanie własne na podstawie wyników badań ankietowych.

Uzyskane wyniki badań wskazuja, że bezrobotne osoby młode stosunkowo rzadko korzystają z metod poszukiwania zatrudnienia, które wymagają od nich większego 
zaangażowania i odpowiedniego przygotowania. Do takich form zalicza się między innymi bezpośrednie wizyty w zakładach pracy czy wysyłanie ofert do pracodawców. Należy również zaznaczyć, że brak jest wyraźnego związku pomiędzy stosowaniem określonej metody szukania pracy a poziomem wykształcenia osób bezrobotnych.

\section{Stwierdzenia i wnioski}

1. Wyniki badań wskazują na bardzo niski stopień korzystania przez młode osoby bezrobotne $\mathrm{z}$ aktywnych instrumentów rynku pracy. $\mathrm{Z}$ tego typu programów skorzystało zaledwie 26 respondentów (21,6\% ogółu badanych). Ankietowani bezrobotni korzystali przede wszystkim ze staży i szkoleń. W każdym przypadku szkolenia dotyczyły tematyki uruchomienia i prowadzenia własnej działalności gospodarczej. Niewielki stopień wykorzystania instrumentów aktywnych wynika przede wszystkim z braku przekonania młodych osób bezrobotnych o skuteczności tego typu rozwiązań.

2. Jako bardzo niski należy ocenić poziom wiedzy respondentów w zakresie funkcjonowania programów aktywizujących. Najwyższy poziom wiedzy deklarowały w odniesieniu do dotacji na uruchomienie własnej działalności oraz pożyczki na założenie własnej firmy. Można sądzić, że przyczyna tego stanu rzeczy leży nie tylko po stronie bezrobotnych, ale również jest rezultatem mało skutecznej komunikacji powiatowych urzędów pracy z osobami bezrobotnymi.

3. W celu poszukiwania zatrudnienia osoby badane najczęściej śledziły oferty urzędów pracy i oferty publikowane w mediach oraz korzystały z kontaktów swoich krewnych i znajomych. Uzyskane wyniki badań wskazują, że bezrobotne osoby młode stosunkowo rzadko korzystają $\mathrm{z}$ metod, które wymagają od nich większego zaangażowania i odpowiedniego przygotowania. Największą aktywność w zakresie poszukiwania pracy wykazywały osoby legitymujące się wykształceniem średnim (przeciętnie stosowały 5 różnorodnych metod). Wyniki badań wskazują jednocześnie na brak wyraźnego związku pomiędzy stosowaniem określonej metody poszukiwania zatrudnienia a poziomem wykształcenia osób bezrobotnych.

4. Niska aktywność w zakresie korzystania $\mathrm{z}$ programów rynku pracy pozostaje w sprzeczności ze strukturą badanej zbiorowości. Wśród respondentów dominującą grupę stanowiła kategoria bezrobotnych, którzy utracili zatrudnienie. W sytuacji dobrej koniunktury gospodarczej i zgłaszanych przez przedsiębiorców niedoborów pracowniczych można przypuszczać, że są to między innymi bezrobotni, których umiejętności i kompetencje zawodowe nie spełniały oczekiwań pracodawców, a które mogłyby być uzupełnione i poszerzone przy wykorzystaniu aktywnych instrumentów rynku pracy.

Uwzględniając statystyki bezrobocia młodych mieszkańców wsi podregionu siedleckiego oraz uzyskane wyniki badań ankietowych należy sądzić, że obniżenie natężenia problemu bezrobocia młodych mieszkańców wsi wymaga zwiększonej aktywności instytucji rynku pracy, w tym przede wszystkim publicznych służb zatrudnienia oraz Ochotniczych Hufców Pracy wyspecjalizowanych w działaniach na rzecz osób bezrobotnych do 25 roku życia. Zwiększenie aktywności powinno dotyczyć zarówno działań skierowanych do bezrobotnych, jak również tych skierowanych do pracodawców. 


\section{Literatura}

Aktywność ekonomiczna ludności Polski I kwartał 2016 (Labour force survey in Poland I quarter 2016). (2016). GUS. Warszawa.

Aktywność ekonomiczna ludności Polski I kwartał 2018 (Labour force survey in Poland I quarter 2018). (2018). GUS. Warszawa.

Bezrobocie rejestrowane I kwartał 2018 r. (Registered unemployment I quarter 2018). (2018). GUS. Warszawa.

Bezrobotni o swojej sytuacji życiowej. Komunikat z badań (The unemployed about their situation. Survey repor). (2007). CBOS. Warszawa

Chłoń-Domińczak, A., Strawiński, P. (2015). Wchodzenie młodych osób na rynek pracy w Polsce (Integration of young people in the Polish labour market). W: E. Kwiatkowski, B. Liberada (red.). Determinanty rozwoju Polski. Rynek pracy i demografia (s. 27-39). Polskie Towarzystwo Ekonomiczne. Warszawa.

Drela, K., Kiernożycka-Sobejko, A. (2009). Ekonomizacja rynku pracy w XXI. wieku (Economisation of the labour market of the $21^{\text {st }}$ century). Wydawnictwo Naukowe Uniwersytetu Szczecińskiego. Szczecin.

Fraczek, M. (2015). Instrumenty, finansowanie i efektywność polityki rynku pracy w Polsce (Instruments, funding and effectiveness of the labour market policy in Poland). W: M. Frączek (red.). Polityka rynku pracy. Teoria i praktyka (s. 119-130). Polskie Wydawnictwo Ekonomiczne. Warszawa.

Frączek, M. (2015). Cele, rodzaje i efekty polityki rynku pracy (Objectives, types and effects of labour market policy). W: M. Frączek (red.). Polityka rynku pracy. Teoria i praktyka (s. 45-53). Polskie Wydawnictwo Ekonomiczne. Warszawa.

Jelonek, M., Kasperek, K., Magierowski, M. (2015). Młodzi na rynku pracy - pracownicy, przedsiębiorcy, bezrobotni (Young people on the labour market - the employees, entrepreneurs, unemployed). Polska Agencja Rozwoju Przedsiębiorczości. Warszawa.

Kaczmarczyk, K. (2016). Bierność i bezrobocie młodzieży w Polsce (Inactivity and youth unemployment in Poland). Wydawnictwo UMK. Toruń.

Kobylińska, U., Kozłowski, A., Rollnik-Sadowska, A., Samul, J. (2016). Sytuacja osób młodych na rynku pracy w województwie podlaskim (Situation of young people on the Podlaskie Province labour market) Wojewódzki Urząd Pracy w Białymstoku, Politechnika Białostocka. Białystok.

Kubiak, P. (2016). Pasywna polityka rynku pracy w Polsce w okresie kryzysu finansowego i gospodarczego (Passive labour market policy in Poland in light of financial and economic crisis). Studia Ekonomiczne. Zeszyty Naukowe UE w Katowicach, 257, 7-17.

Księżyk, M. (2015). Ekonomia współczesnej gospodarki rynkowej (Economics of the contemporary market economy). Wydawnictwo Akademii Górniczo-Hutniczej im. S. Staszica. Kraków.

Ostój, I. (2012). Formalne i nieformalne instytucje rynku pracy (Formal and informal labour market institutions) Wyd, UE. W Katowicach.

Piróg, D. (2013). Absolwenci szkół wyższych na rynku pracy w warunkach kryzysu (Higher education graduates on the labour market in times of an economic crisis). Przedsiębiorczość-Edukacja, 9, 302-316.

Socha, M., Sztanderska, U. (2000). Strukturalne podstawy bezrobocia w Polsce (The bases of structural unemployment in Poland). Wydawnictwo Naukowe PWN, Warszawa.

Witkowski, J. (2005). Specyfika wiejskiego rynku pracy w Polsce (Unique characteristics of the Polish labour market). Kontrola Państwowa. Nr 2, 33-34.

Do cytowania / For citation:

Rak A.M. (2018). Aktywizacja zawodowa młodych osób bezrobotnych w wybranych powiatach ziemskich podregionu siedleckiego. Problemy Rolnictwa Światowego, 18(3), 262-271;

DOI: $10.22630 /$ PRS.2018.18.3.84

Rak A.M. (2018). Vocational Activation of Young Unemployed in Selected Rural Counties of Siedlce Subregion (in Polish). Problems of World Agriculture, 18(3), 262-271;

DOI: $10.22630 /$ PRS.2018.18.3.84 